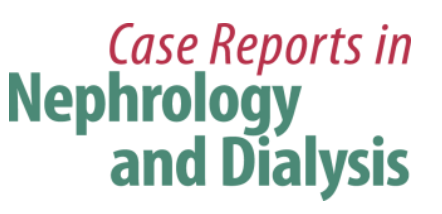

Case Rep Nephrol Dial 2017;7:6-12

\title{
Neurotoxicity following the Ingestion of Bilimbi Fruit (Averrhoa bilimbi) in an End-Stage Renal Disease Patient on Hemodialysis
}

\author{
Camille Pereira Caetano ${ }^{a}$ Cinara Barros de Sáa \\ Bruno Antônio Paixão Faleiros ${ }^{a}$ \\ Marcelo Fonseca Coutinho Fernandes Gomes ${ }^{a}$ Edna Regina Silva Pereira ${ }^{b}$ \\ ${ }^{a}$ Division of Internal Medicine, Urgency Hospital of Goiânia, Goiânia, Brazil; \\ ${ }^{b}$ Department of Internal Medicine, Federal University of Goiás, Goiânia, Brazil
}

\section{Keywords}

Foodborne diseases - Averrhoa - Epileptic status - Chronic kidney disease

\begin{abstract}
Introduction: The toxic effects of the ingestion of star fruit (Averrhoa carambola) in chronic kidney disease patients are well described in the literature. Recently, the compound caramboxin has been isolated, explaining the mechanisms of its neurotoxicity. Bilimbi fruit belongs to the family Oxalidaceae, Averrhoa bilimbi species, and exhibits similar biochemical characteristics to star fruit. Objective: To report the case of a patient with chronic kidney disease who developed a seizure disorder after the ingestion of bilimbi fruit. Case Report: A 69-yearold man with chronic kidney disease on hemodialysis therapy had intractable hiccups, myoclonus, and generalized tonic-clonic seizures after the consumption of a moderate amount of bilimbi fruit. The electroencephalogram showed a pattern of seizure disorder despite the use of anticonvulsant drugs. Renal replacement therapy was maintained during the whole period and prescribed according to the patient's hemodynamic status. Despite showing clinical resolution of the seizure disorder, the patient died on the 27th day of hospitalization for infectious complications. Conclusions: The neurologic status without any other known cause and with clear temporal association with the ingestion of the fruit suggests the diagnosis of
\end{abstract}




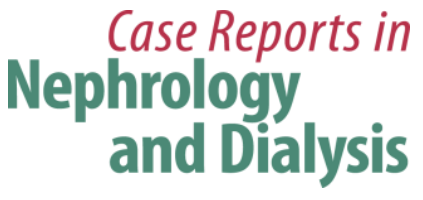

Case Rep Nephrol Dial 2017;7:6-12

DOI: $10.1159 / 000454945$

(C) 2017 The Author(s). Published by S. Karger AG, Basel www.karger.com/cnd

Caetano et al.: Neurotoxicity following the Ingestion of Bilimbi Fruit (Averrhoa bilimbi) in an End-Stage Renal Disease Patient on Hemodialysis

neurotoxicity. We propose the hypothesis that the bilimbi fruit has neurotoxic effects similar to those exhibited by the star fruit.

\section{Introduction}

The first case of neurotoxicity of the star fruit (Averrhoa carambola) was described in Malaysia in the in an experimental study showing a depressant effect on the central nervous system in mice after intraperitoneal administration of the fruit extract, leading to seizures [1]. In Brazil, the first clinical description of the toxic effects of star fruit ingestion in chronic kidney disease (CKD) patients on hemodialysis was by Martin et al. [2] in Botucatu in 1993, who reported on 8-10 patients with intractable hiccups that improved with hemodialysis [2]. However, it was only in 1998 that the hypothesis of the neurotoxicity of star fruit was consolidated by a study including 6 patients conducted at Ribeirão Preto Medical School reporting hiccups, psychomotor agitation, seizures, and death [3].

Recently, the neurotoxin caramboxin, a phenylalanine-like molecule with glutamatergic ionotropic action, has been isolated, explaining the mechanism of neurotoxicity related to the ingestion of star fruit [4]. This neurotoxin seems to specifically inhibit the GABAergic system [5].

Patients at CKD stages 3-4 are more likely to become intoxicated after the ingestion of star fruit. Clinical manifestations of the intoxication may be mild, moderate, or severe, and the most common symptoms are hiccups, vomiting, insomnia, agitation, paresthesia, paraplegia, confusion, seizures, hemodynamic instability, and shock [6].

In addition, the risk for acute kidney injury (AKI) has been described in healthy individuals after star fruit ingestion; this has been ascribed to its high concentration of oxalic acid. Oxalate is a nephrotoxic agent that, when consumed under fasting conditions, accumulates in the kidney tubules and their cells, leading to AKI [7].

Averrhoa bilimbi, also known as bilimbi fruit, cucumber tree, or tree sorrel, belongs to the Averrhoa carambola family Oxalidacae, with probable origin in Southeast Asian [8,9]. Bilimbi fruit is cylindrical, with five, rounded, longitudinal lobes, produced in clusters, and has a yellowish green color when ripe (Fig. 1). Due to its high acidity when immature, bilimbi fruit is usually used in the production of vinegars, pickles, and as a substitute for lemon in seasoning. When ripe, the fruit can be consumed fresh or cooked in the form of compote or jam $[8,9]$. The juice is rich in vitamin $\mathrm{C}$ and oxalic acid [9].

Averrhoa bilimbi species has similar physical and biochemical characteristics to star fruit [10]. From a clinical standpoint, AKI caused by oxalate deposits has been described, similarly to that occurring after the ingestion of large amounts of star fruit. In 2013, Bakul et al. [11] described 10 cases of acute intoxication and oxalate-induced AKI due to the ingestion of Averrhoa bilimbi juice. A similar case has been reported in Brazil in 2014, involving a patient with previously normal kidney function who developed AKI after the ingestion of bilimbi fruit juice under fasting conditions [12]. The mechanisms of bilimbi-related nephrotoxicity are the same as those related to star fruit consumption.

To our knowledge, no cases of neurotoxicity have been reported due to bilimbi fruit ingestion in CKD patients. This study aimed to describe the case of a CKD patient on renal replacement therapy who developed neurologic symptoms after the ingestion of bilimbi fruit, similar to those related to star fruit ingestion. 


\section{Case Reports in Nephrology and Dialysis}

\begin{tabular}{l|l}
\hline DOI: 10.1159/000454945 & (C) 2017 The Author(s). Published by S. Karger AG, Basel \\
\hline
\end{tabular} www.karger.com/cnd

Caetano et al.: Neurotoxicity following the Ingestion of Bilimbi Fruit (Averrhoa bilimbi) in an End-Stage Renal Disease Patient on Hemodialysis

\section{Clinical Case}

We report the case of a 69-year-old male patient with hypertension and CKD stage 5 of undefined etiology on hemodialysis for 4 years. Two days before hospitalization, the patient consumed 6 bilimbi fruits of greenish coloration. Three hours later, the patient started having uncontrollable hiccups, malaise, abdominal discomfort, and two episodes of macroscopic hematuria. Twenty hours later, the patient still had hiccups and started to experience nausea and vomiting. Twenty-four hours later, the patient continued with abdominal discomfort and significant asthenia, followed by a decrease in the level of consciousness, dysarthria, and myoclonus of the upper limbs, which led to first, generalized, tonic-clonic seizures that progressed to subsequent seizures despite therapeutic doses of phenytoin.

The patient was transferred to a referral emergency service in Goiânia, Brazil, with refractory seizures. At admission, the patient was under mechanical ventilation by orotracheal intubation. At physical examination, the patient was under sedation, had a Richmond Agitation Sedation Scale score of -3 , was hemodynamically stable, with a blood pressure of $110 / 60 \mathrm{~mm} \mathrm{Hg}$, and a heart rate of $68 \mathrm{bpm}$. The patient also had some diffuse ecchymoses on the trunk and extremities, probably due to the trauma of seizures (Fig. 2).

At admission, complementary tests revealed: hemoglobin of $13.1 \mathrm{~g} / \mathrm{dL}$, hematocrit of $39.3 \%$, white blood cells of $13,600 / \mathrm{mL}$ (band form count of 3\%), and 179,000 platelets $/ \mathrm{mL}$; urea blood levels of $86.8 \mathrm{mg} / \mathrm{dL}$, serum creatinine of $7.11 \mathrm{mg} / \mathrm{dL}$, serum sodium of 139 $\mathrm{mEq} / \mathrm{L}$, and serum potassium of $3.93 \mathrm{mEq} / \mathrm{L}$. A computed tomography of the head revealed hypoattenuation in the periventricular deep white matter and centrum semiovale, probably related to gliosis or microangiopathy.

Lumbar puncture revealed transparent, colorless cerebrospinal fluid, the presence of 22 red blood cells (probably due to accidental puncture), and normal concentrations of glucose, white blood cells, and proteins. Negative results were obtained from the bacterial test, China ink test, analysis for fungi, and acid-fast staining.

The patient was transferred to the intensive care unit, receiving phenytoin and midazolam. The first 6-h session of sustained low-efficiency daily dialysis (SLEDD) was started, which had to be discontinued before completion due to severe hypotension. The patient was using an indwelling urinary catheter, and macroscopic hematuria was detected.

On the third day of hospitalization, the patient had to receive norepinephrine due to hemodynamic worsening. Also, the laboratory tests showed a worsening of the infectious process: hemoglobin of $12.5 \mathrm{~g} / \mathrm{dL}$, hematocrit of $38.8 \%$, white blood cells of $16,700 / \mathrm{mL}$ (band form count of $8 \%$ ), 180,000 platelets $/ \mathrm{mL}$, and an increase in C-reactive protein (CRP) levels to $320 \mathrm{mg} / \mathrm{dL}$. Antibiotic therapy was started with piperacillin-tazobactam for the treatment of septic shock secondary to ventilator-associated tracheobronchitis.

On the fourth day of hospitalization, as the patient continued with seizures during attempts to reduce the dose of the sedative medications, and with no definite diagnosis, further tests were ordered for diagnostic investigation. Although the SLEDD sessions had to be discontinued due to hemodynamic instability, the patient seemed to improve from the infection. Since the diagnostic hypothesis of central nervous system vasculitis had been raised, immunosuppression with intravenous methylprednisolone for 3 consecutive days was the treatment of choice. The search for rheumatic diseases carried out was negative.

On the fifth day of hospitalization, electroencephalogram (EEG) detected epileptogenic activity, suggestive of seizure disorder, and thiopental was added to the patient's treatment. On this day, the family confirmed that the patient had consumed bilimbi fruit before the onset of the symptoms. 


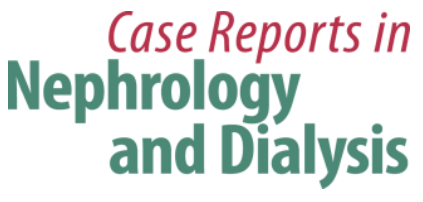

Case Rep Nephrol Dial 2017;7:6-12

DOI: $10.1159 / 000454945$

(C) 2017 The Author(s). Published by S. Karger AG, Basel www.karger.com/cnd

Caetano et al.: Neurotoxicity following the Ingestion of Bilimbi Fruit (Averrhoa bilimbi) in an End-Stage Renal Disease Patient on Hemodialysis

On the eighth day of hospitalization, the epileptogenic activity was still confirmed by EEG, which also detected a decrease in paroxysmal activity. Therapy with thiopental, midazolam, and valproic acid was continued and also an attempt to intensify hemodialysis.

On the tenth day of hospitalization at the intensive care unit, an EEG suggested improvement of the seizure disorder. Thiopental and midazolam were gradually decreased, and valproic acid increased.

On the twelfth day of hospitalization, the dose of noradrenaline had to be increased. The patient had a fever $\left(38.5^{\circ} \mathrm{C}\right)$ and worsening of the laboratory test results: lactate of 3.9 $\mathrm{mmol} / \mathrm{L}$, white blood cells of 21,500/mL (band form count of 9\%), and CRP of $107 \mathrm{mg} / \mathrm{dL}$. With a diagnostic hypothesis of septic shock of unknown origin, he was started on the antibiotics meropenem, vancomycin, and gentamicin, and blood, tracheal aspirate, and catheter samples were collected. Isolates of multidrug-resistant Klebsiella pneumoniae were cultured from tracheal aspirates, which were sensitive only to tigecycline. The antibiotic was then started.

After 14 days of hospitalization, the patient was conscious and responsive, with no sedatives, and he had received decreasing doses of noradrenaline. The patient had persistent myoclonus in the lower limbs, but with no new episodes of generalized tonic-clonic seizures. SLEDD was maintained with low clinical tolerability.

On the 23rd day of hospitalization, there was a worsening of the clinical status with a progressive increase in vasoactive drug doses. The patient was still on hemodialysis, continued to have a fever, leukocytosis, and increased CRP levels. On the 27th day of hospitalization, the patient died of circulatory failure.

\section{Discussion}

Here we describe the case of a CKD patient on hemodialysis who developed intractable hiccups, decreased consciousness levels, and subsequent seizure disorder after the ingestion of a moderate amount of bilimbi fruit. After complications of a prolonged hospital stay, the patient died.

Intoxication following star fruit ingestion in CKD patients is a well-described phenomenon, and the most common symptom is hiccups, usually intractable, that do not respond to conventional drugs. Generally, hiccups begin $2-3 \mathrm{~h}$ after the ingestion of the fruit [13]. This case had a similar course to that reported in CKD patients following star fruit ingestion regarding time of onset for hiccups followed by a decrease in consciousness $[6,13]$. Hematuria may be explained by oxalate deposits in the renal tubules, as previously hypothesized [12]. We cannot affirm that the hemodynamic instability experienced by the patient since the first hemodialysis session was also caused by the exogenous intoxication. Nevertheless, it is worth mentioning that hemodynamic instability has also been described as a clinical complication of intoxication from star fruit ingestion [6]. The unfavorable course of this case is in agreement with previous reports in the literature, describing seizure as a bad prognostic factor. Seizure occurs in up to $30 \%$ of all cases of intoxication following star fruit ingestion, and the mortality is higher among patients who experience this symptom [14]. Although most patients improve with hemodialysis, some patients have a more fulminant course and die, regardless of the therapy received [15].

The strong time-relationship between the ingestion of moderate amounts of these fruits (both belong to the same family and share similar physical and biochemical characteristics) 
and the onset of symptoms in a CKD patient is strongly suggestive of intoxication from the possible content of caramboxin in both fruits.

The toxicity associated with the consumption of bilimbi fruit seems to be a rare event, since we did not find any other case in the literature. However, in a recent report [12] of AKI associated with the ingestion of bilimbi fruit juice, the patient also experienced intractable hiccups, and the hypothesis that the symptom was caused by a neurotoxin similar to caramboxin was not ruled out.

This report illustrates the difficulty in describing the actual etiology of neurologic manifestations as well as the severity and refractory nature of symptoms in this patient. Studies that demonstrate the relationship between the consumption of bilimbi fruit and neurologic condition are still needed. However, similarities between this case report and others that described intoxication from star fruit ingestion in CKD patients and similar features shared by these fruits suggest that bilimbi fruit contains the same neurotoxin caramboxin isolated from the star fruit.

\section{Disclosure Statement}

The authors have no conflicts of interest to declare.

\section{Statement of Ethics}

We obtained written informed consent from the patient's family and approval of the Ethics Committee of the Urgency Hospital of Goiânia.

\section{References}

1 Muir CK, Lam CK: Depressant action of Averrhoa carambola. Med J Malaysia 1980;34:279-280.

2 Martin LC, Caramori JST, Barretti P, Soares VA: Soluço intratável desencadeado por ingestão de carambola (Averrhoa carambola) em portadores de insuficiência renal crônica. J Bras Nefrol 1993;15:92-94.

3 Neto MM, Robl F, Netto JC: Intoxication by star fruit (Averrhoa carambola) in six dialysis patients? Nephrol Dial Transplant 1998;13:570-572.

4 Garcia-Cairasco N, Moyses-Neto M, Del Vecchio F, et al: Elucidating the neurotoxicity of the star fruit. Angew Chem Int Ed Engl 2013;52:13067-13070.

5 Carolino RO, Beleboni RO, Pizzo AB, et al: Convulsant activity and neurochemical alterations induced by a fraction obtained from fruit Averrhoa carambola (Oxalidaceae: Geraniales). Neurochem Int 2005;46:523-531.

-6 Moreira FG, Iervolino RL, Dall'Orto SZ, Beneventi ACA, Oliveira Filho JL, Góis AFT: Intoxicação por carambola em paciente com insuficiência renal crônica: relato de caso. Rev Bras Ter Intensiva 2010;22:395-398.

7 Neto MM: Carambola como causa de lesão renal aguda. J Bras Nefrol 2014;36:118-120.

8 Araujo ER, Alves LIF, Rêgo ER, Rêgo MM, Castro JP, Sapucay MJLC: Caracterização físico-química de frutos biri-biri (Averrhoa bilimbi L). Ver Biotemas 2009;22:225-230.

9 Souza LM, Silva GC, Moraes TM, Barreto LP: Caracterização físico-química do biribiri (Averrhoa bilimbi L). Apresentado e publicado nos anais da IX Jornada de Ensino, Pesquisa e Extensão da UFRPE. Recife 2009. Disponível em: http://www.eventosufrpe.com.br/jepex2009/cd/resumos/R1199-4.pdf

10 Figueredo BG: Caracterização físico-química e compostos biativos de frutos biribiri (Averrhoa bilimbi L.). Itapetinga: UESB, 2014.

11 Bakul G, Unni VN, Seethaleksmy NV, et al: Acute oxalate nephropathy due to 'Averrhoa bilimbi' fruit juice ingestion. Indian J Nephrol 2013;23:297-300. 


\section{Case Reports in Nephrology and Dialysis}

12 Paschoalin RP, Jesus LAS, Paschoalin NP, Silva CAB, Neto MM: Lesão renal aguda como complicação da ingestão excessiva de suco do fruto biri biri (Averrhoa bilimbi). J Bras Nefrol 2014;36:545-548.

13 Neto M, Batista MEP, Vieira OM, et al: Intoxicação por carambola (Averrhoa carambola) em quatro pacientes renais crônicos pré-dialíticos e revisão da literatura. J Bras Nefrol 2005;4:228-232.

14 Tsai MH, Chang WN, Lui CC, et al: Status epilepticus induced by star fruit intoxication in patients with chronic renal disease. Seizure 2005;14:521-525.

15 Alessio-Alves FF, de Souza CP, da Silva LK, Moyses-Neto M, Pontes-Neto OM: Star fruit neurotoxicity mimicking an acute brain stem stroke. Clin Neurol Neurosurg 2012;114:684-685.

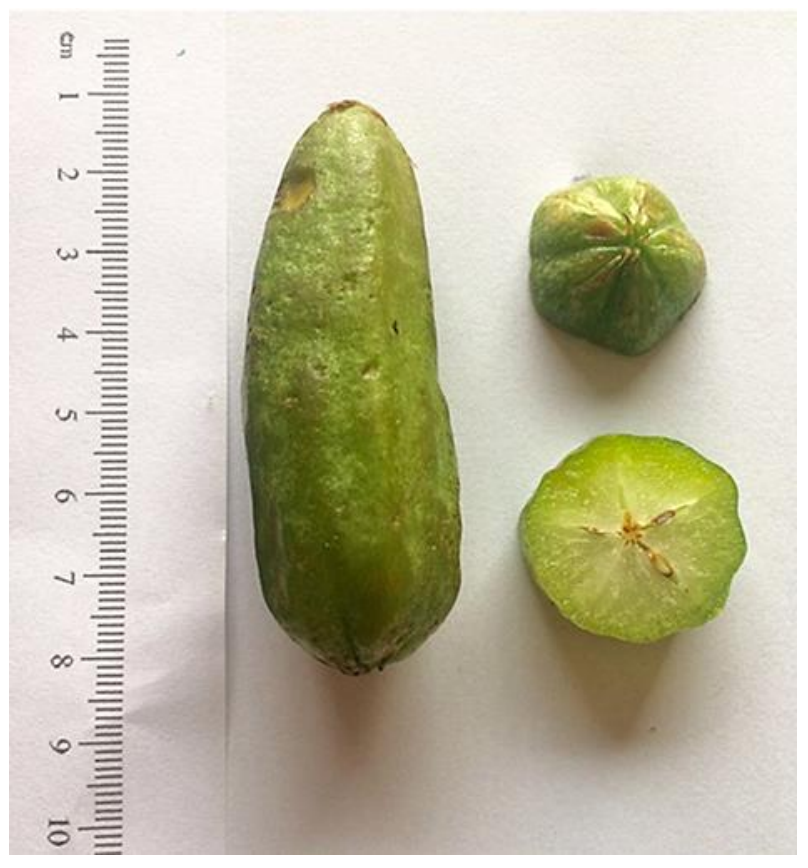

Fig. 1. Photograph of a bilimbi fruit. Longitudinal and cross section. 


\section{Case Reports in Nephrology and Dialysis}

Case Rep Nephrol Dial 2017;7:6-12

DOI: $10.1159 / 000454945$ (c) 2017 The Author(s).
www.karger.com/cnd

Caetano et al.: Neurotoxicity following the Ingestion of Bilimbi Fruit (Averrhoa bilimbi) in an End-Stage Renal Disease Patient on Hemodialysis

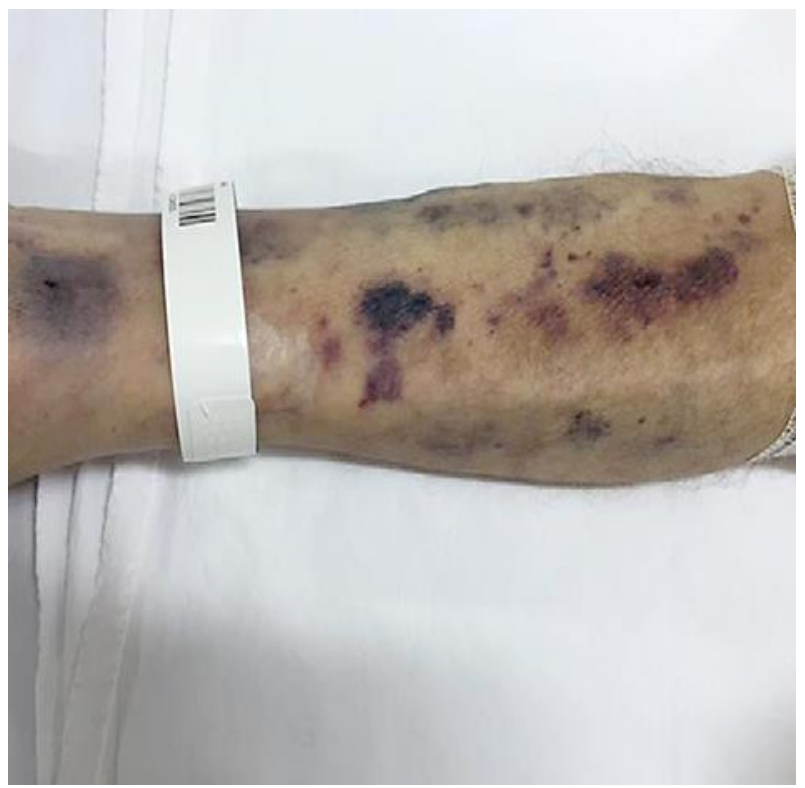

Fig. 2. Diffuse ecchymosis on the lower limbs. 